\title{
Isolation of a novel aquatic birnavirus from rainbow trout Oncorhynchus mykiss in Australia
}

\author{
Christina McCowan ${ }^{1, *}$, Julian Motha ${ }^{1}$, Mark St. J. Crane ${ }^{2}$, Nicholas J. G. Moody ${ }^{2}$, \\ Sandra Crameri ${ }^{2}$, Alex D. Hyatt ${ }^{2}$, Tracey Bradley ${ }^{3}$
}

\author{
${ }^{1}$ Victorian Department of Economic Development, Jobs, Transport and Resources, Agriculture Productivity Division, \\ 5 Ring Road, Bundoora, Victoria 3083, Australia \\ ${ }^{2}$ CSIRO Australian Animal Health Laboratory, 5 Portarlington Road, Geelong, Victoria 3220, Australia \\ ${ }^{3}$ Victorian Department of Economic Development, Jobs, Transport and Resources, Regulation and Compliance Group, \\ 475 Mickleham Rd, Attwood, Victoria 3049, Australia
}

\begin{abstract}
In November 2010, a rainbow trout (Oncorhynchus mykiss) hatchery in Victoria reported increased mortality rates in diploid and triploid female fingerlings. Live and moribund fish were submitted for laboratory investigation. All fish showed hyperpigmentation of the cranial half of the body. Histological lesions were seen in all areas of skin examined despite the localised nature of the gross lesions. There was irregular hyperplasia and spongiosis, alternating with areas of thinning and architectural disturbance. Occasionally, particularly in superficial layers of epithelium, cells showed large, eosinophilic inclusions that obscured other cellular detail. A small number of fish had necrosis in dermis, subcutis and superficial muscles. Bacteriological culture of skin and gills was negative for all bacterial pathogens, including Flavibacterium columnare, the agent of columnaris disease. Attempts at virus isolation from the skin of affected fish resulted in the development of a cytopathic effect in RTG-2 cell cultures suggestive of the presence of a virus. Negative contrast electron microscopy of cell culture supernatant demonstrated the presence of viral particles with the typical morphology of birnaviruses. Preliminary molecular characterisation identified an aquabirnavirus that differed from both the Tasmanian aquabirnavirus (TABV) and other aquabirnaviruses exotic to Australia. Previous isolates of aquabirnaviruses in Australia and New Zealand have been from healthy fish in a marine environment. This is the first report of an aquabirnavirus isolated from young salmonids at a freshwater hatchery in Australia. The role of the virus in the mortality event on the farm is uncertain as no further deaths attributable to this virus have occurred in the $4 \mathrm{yr}$ since its initial discovery. The virus has been provisionally named Victorian trout aquabirnavirus (VTAB).
\end{abstract}

KEY WORDS: Aquabirnavirus · Rainbow trout $\cdot$ Oncorhynchus mykiss $\cdot$ Australia Resale or republication not permitted without written consent of the publisher

\section{INTRODUCTION}

Double-stranded, bisegmented RNA viruses of the family Birnaviridae are the most ubiquitous of pathogenic micro-organisms of aquatic animal species and are found in both marine and freshwater fish (Rodriguez Saint-Jean et al. 2003, Roberts \& Pearson 2005). The genus Aquabirnavirus includes both viru- lent and avirulent species (Reno 1999). The best known and most characterised aquatic birnavirus is infectious pancreatic necrosis virus (IPNV), the type virus of the genus Aquabirnavirus and a significant pathogen of salmonids in the northern hemisphere (Roberts \& Pearson 2005). This virus is a cause of significant mortality in young salmonids, particularly post-smolt rainbow trout Oncorhynchus mykiss Wal- 
baum and brook trout Salvelinus fontinalis Mitchill (Reno 1999), but also in Atlantic salmon Salmo salar L. fry and fingerlings (Roberts \& Pearson 2005). Clinical signs of IPNV infection are non-specific, including external darkening, exophthalmos, petechiation in fins and gill pallor (Roberts \& Pearson 2005). Adult fish can be subclinical carriers; both horizontal transmission from infected water, infected fish, filter feeders and faeces of piscivorous birds, and vertical transmission through gonadal fluids but not gametes have been reported (Roberts \& Pearson 2005).

Aquabirnaviruses have been isolated from salmonids in both Australian and New Zealand waters, but in both instances the isolates have been found in marine-phase fish only, never from freshwater hatcheries, and they were not associated with disease (Tisdall \& Phipps 1987, Crane et al. 2000). These countries are thus considered to be free of infectious pancreatic necrosis.

In November 2010, a novel aquatic birnavirus was isolated from rainbow trout fry during an episode of mortality in a hatchery in Victoria (south-eastern Australia). The mortality episode resolved itself, has not recurred, and no further losses have been reported, leaving the role of this virus in the deaths uncertain.

\section{MATERIALS AND METHODS}

Affected fish and submission of samples. A rainbow trout (Oncorhynchus mykiss) hatchery in Victoria reported increased mortality in 3-mo-old, diploid and triploid female fingerlings, averaging about $3 \mathrm{~g}$. The population numbered about 380000 fish, and the farm was losing about $10 \mathrm{~kg} \mathrm{~d}^{-1}$ (or 3000 to 4000 fish). The farmer believed that the event coincided with a period of unusually high water temperatures. Mortality rates subsided over an unspecified period of time and had returned to normal by $3 \mathrm{wk}$ following the restoration of lower temperatures by release of dam water to the river. Submission of fish for diagnostic investigation occurred in the later stages of the outbreak, when water temperatures were low (12 to $\left.14^{\circ} \mathrm{C}\right)$.

Fish on the farm had suffered a mild to moderate outbreak of Ichthyophthirius multifiliis (white spot disease) approximately 2 wk previously, but trophont counts from skin scrapes were performed on the farm and indicated that white spot was no longer an issue. The farmer noted a change in body colour, sometimes in a saddle pattern around the dorsal fin, flaring of opercula and 'tail rot' in some of the fish, and suspected columnaris disease as the cause. A pool of 18 live and moribund fish from 3 affected populations was submitted to the diagnostic laboratory; 10 fish were autopsied, and samples were fixed in $10 \%$ neutral buffered formalin for microscopy. Of these 10 , skin scrapings and gill clips were taken from 5 fish prior to fixation.

Histopathology. Using routine procedures, tissues from the 10 autopsied fish were trimmed, processed and stained with haematoxylin and eosin. Skin, gills and other organs including coelomic viscera, brain and eyes were examined. Gills were also stained with Gram stain and periodic acid-Schiff (PAS) stain to highlight bacteria or fungi.

Bacteriology. Samples of skin and gills were taken from 6 fish for bacteriological examination. Direct smears were examined, and culture was performed according to standard protocols using sheep blood agar for both samples. For gills, freshwater Ordal's agar and Sabouraud's agar were used at $25^{\circ} \mathrm{C}$ for a minimum of $3 \mathrm{~d}$.

Virus isolation. Routine virus isolation was performed on pooled tissue taken by deep scraping of hyperpigmented skin from 3 fish, using cultures of RTG-2 (rainbow trout gonad; ATCC Catalogue No. CCL55) and FHM (fat head minnow; ATCC Catalogue No. CCL42) cell lines established in $25 \mathrm{~cm}^{2}$ culture flasks and incubated at $20^{\circ} \mathrm{C}$. In the absence of histological lesions, other organs were not examined.

A flask of RTG-2 cells showing cytopathic effect (CPE) typical of viral infection was submitted (Accession Number 10-04677) to CSIRO's Fish Diseases Laboratory, Australian Animal Health Laboratory (AAHL) in Geelong for further characterisation and exclusion of infectious pancreatic necrosis virus. Culture supernatant was further passaged twice in BF-2 (blue gill fry; ATCC Catalogue No. CCL91) and RTG2 cell lines. For electron microscopy, the virus was also passaged in CHSE-214 (Chinook salmon embryo; ATCC Catalogue No. CRL1681) cells.

Electron microscopy. Negative contrast electron microscopy was used to examine the supernatant from an infected cell culture. Supernatant was adsorbed onto parlodion-filmed 400 mesh copper grids coated with carbon and stained (1 min) with nano-W stain (Nanoprobes). Infected and control RTG-2 and CHSE-214 cells (5 d post-infection) were processed for examination via ultra-thin sections as described in Weir et al. (2012), with the exception that Sorensen's phosphate buffer (300 mOsm kg-1, $\mathrm{pH} 7.2$ ) was used as the buffer. All samples were examined using a Philips CM120 transmission electron microscope at $100 \mathrm{kV}$. 
Molecular analysis. Conventional reverse transcriptase polymerase chain reaction (RT-PCR) using generic aquabirnavirus primers (GABF and GABR) described by Davies et al. (2010) to amplify a $775 \mathrm{bp}$ sequence of Segment A of Tasmanian aquabirnavirus (TABV) and Serogroup A aquabirnavirus strains was undertaken with the SuperScript III One Step RT-PCR with a Platinum Taq kit (Invitrogen, Life Technologies Australia Pty Ltd). The region targeted corresponds to bases 555 to 1330 of IPNV Strain Jasper D (NC_001915). Reaction mixtures, of $25 \mu \mathrm{l}$ final volume containing $2 \mu \mathrm{l}$ template, $12.5 \mu \mathrm{l} 2 \times$ reaction buffer, $1 \mu \mathrm{l}$ Superscript III/Platinum Taq Mix (Invitrogen) and $0.18 \mu \mathrm{M}$ of each primer, were incubated at $50^{\circ} \mathrm{C}$ for $30 \mathrm{~min}, 95^{\circ} \mathrm{C}$ for $2 \mathrm{~min}$, followed by 35 cycles of $95^{\circ} \mathrm{C}$ for $45 \mathrm{~s}, 58^{\circ} \mathrm{C}$ for $45 \mathrm{~s}$ and $68^{\circ} \mathrm{C}$ for $60 \mathrm{~s}$. Final extension was at $68^{\circ} \mathrm{C}$ for 7 min. PCR products were resolved by electrophoresis through $2 \%$ agarose gels in TAE, and the amplicons were visualised by staining with SYBR Safe DNA gel stain (Invitrogen) and blue-light transillumination. Amplicons of the expected size were cut from the gel using sterile scalpel blades and purified from the agarose using a commercial spin column kit according to the manufacturer's instructions (QIAamp PCR Product Purification Kit, QIAGEN).

Davies et al. (2010) reported the presence of a unique ClaI restriction enzyme site within the TABV PCR amplicon, which enabled rapid differentiation from exotic Serogroup A aquabirnavirus strains. Therefore, to confirm/exclude TABV and IPNV while sequencing of amplicons was being undertaken, digestion with the restriction enzyme ClaI was conducted. The reaction mix included $2 \mu \mathrm{l}$ of $10 \times$ reaction buffer, $2 \mu \mathrm{l}$ of bovine serum albumin (BSA; $1 \mathrm{mg} \mathrm{ml}^{-1}$ ), $10 \mathrm{U}$ of $\mathrm{ClaI}$ (Promega Australia), $10 \mu \mathrm{l}$ of eluted amplicon and water to $20 \mu \mathrm{l}$ were incubated at $37^{\circ} \mathrm{C}$ for $90 \mathrm{~min}$. Products were analysed by agarose gel electrophoresis as described above.

Sequences were generated by direct product sequencing using BigDye Terminator v3.1 Cycle Sequencing chemistry and a 3130xl Genetic Analyzer (Applied Biosystems, Life Technologies Australia) according to the manufacturer's instructions. Each amplicon was sequenced using the forward and reverse primers used in the initial RTPCR. Chromatogram analysis and con- sensus sequences and multiple sequence alignments using ClustalW were produced using Geneious Pro (Drummond et al. 2011). Phylogenetic analyses using the neighbour-joining method were conducted using MEGA v5 (Tamura et al. 2011).

Immunocytochemistry. Immunocytochemistry was performed on infected RTG-2 cells using standard procedures with a commercially available sheep anti-IPNV polyclonal antibody IPNV (Microtek International) and the Erwin strain of IPNV (Davies et al. 2010) as the positive control.

\section{RESULTS}

Water data for the section of the river supplying the farm showed that the outbreak began as temperatures exceeded $16^{\circ} \mathrm{C}$. This was higher than temperatures at the same time in previous years (Fig. 1). Water flow rates and oxygenation remained within the ranges experienced in previous months and years (Fig. 2).

Gross pathology. On arrival, approximately half the fish were dead and the remainder were chilled but showed no obvious abnormalities of swimming or proprioception. All fish showed a sharp line of pigmentary demarcation approximately half-way along the body, with the cranial skin having much darker

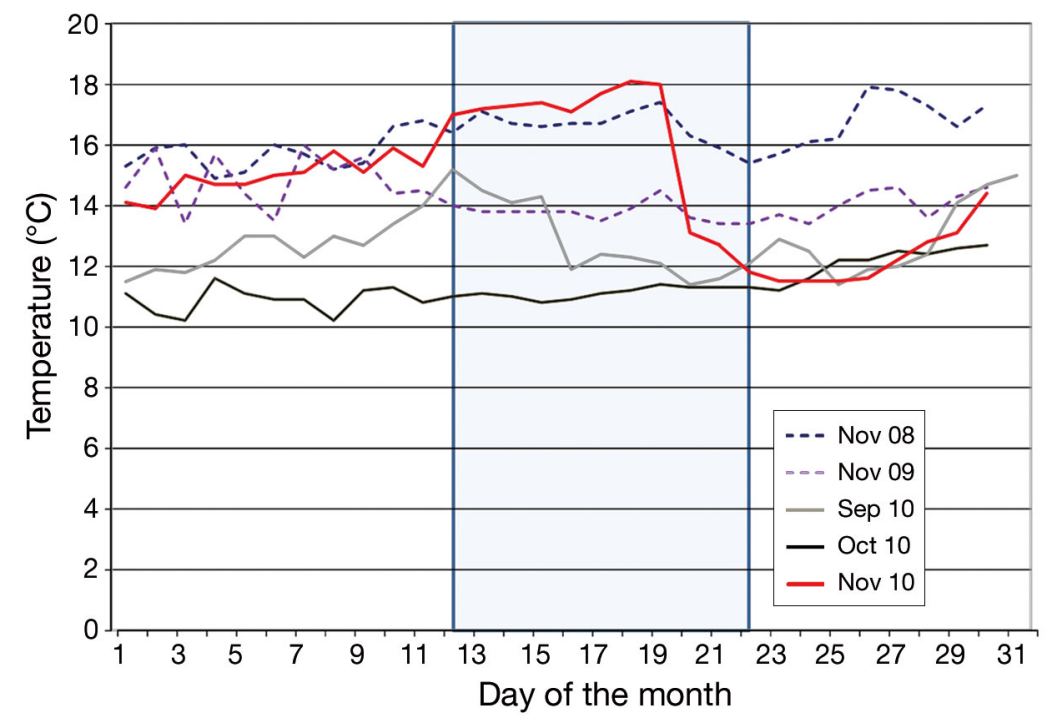

Fig. 1. Record of water temperatures. The period of increased mortality in rainbow trout Oncorhynchus mykiss fry is indicated by the shaded block. Rates increased in conjunction with an increase in water temperature $>16^{\circ} \mathrm{C}$ and declined following restoration of temperatures. The temperatures in November 2010 were higher than those of the preceding months (solid lines) or for the same time in the previous $2 \mathrm{yr}$ (dashed lines) 


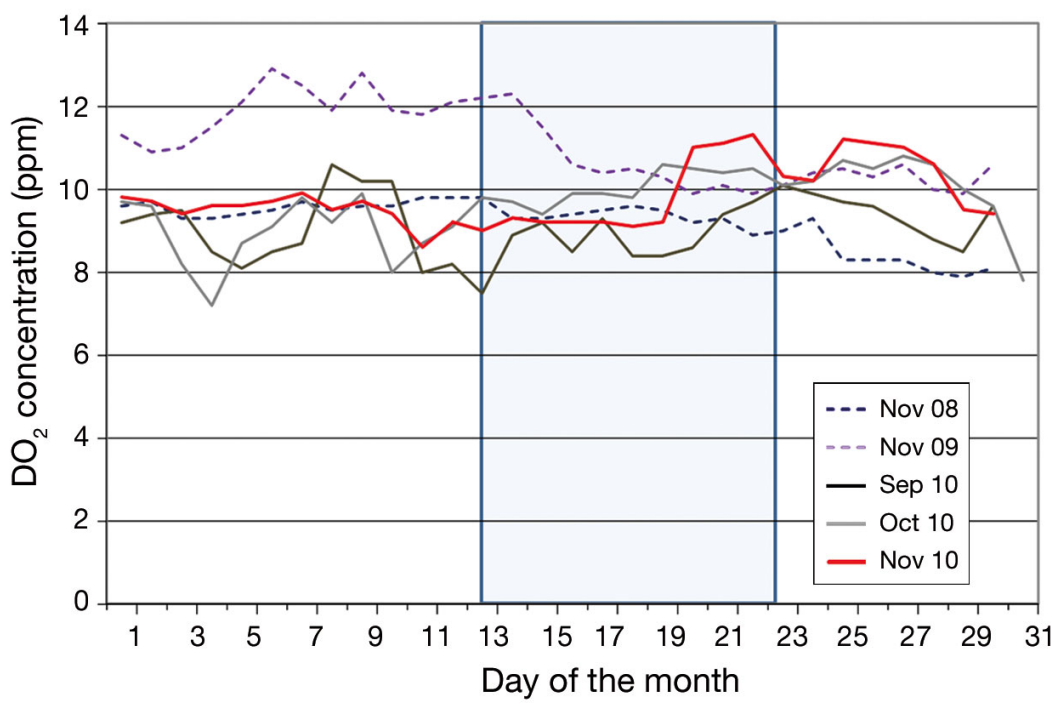

Fig. 2. Record of dissolved oxygen levels $\left(\mathrm{DO}_{2}\right)$. The period of increased mortality in rainbow trout Oncorhynchus mykiss fry is indicated by the shaded block. Dissolved oxygen in the water supply in November 2010 was in the same range as in previous months and years

colouration than the caudal (Fig. 3). Some fish evidenced fraying of the dorsal and/or tail fin. No other gross abnormalities were identified, and no significant changes were seen on wet mounts of skin scrapings from 5 fish.

Histology. Histological lesions were seen in the skin of all fish examined. All areas of skin examined, including both cranial and caudal skin, showed these changes, despite the localised nature of the gross lesions. The epidermis showed irregular hyperplasia and spongiosis, alternating with areas of thinning. Ep-

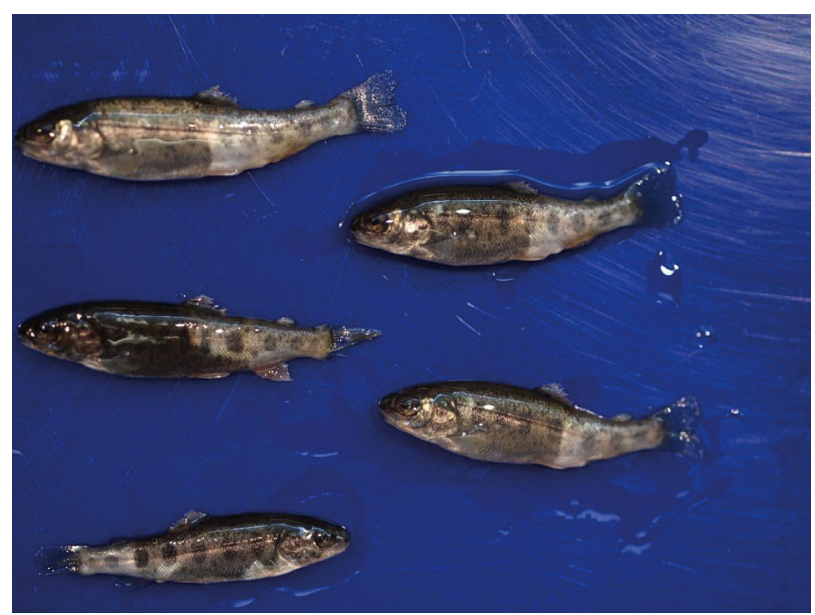

Fig. 3. Oncorhynchus mykiss. Clinical signs of disease. Submitted fish were moribund or dead, and all showed marked colour change cranially ithelial cells were disordered and irregular in size and shape, often with large, pale, cleaved or reniform nuclei and dispersed chromatin. Mitoses occurred occasionally and were not confined to the basal layer, and there were moderate numbers of apoptotic cells, particularly in superficial skin layers. Occasional cells, particularly in superficial layers of the epithelium, showed large cytoplasmic inclusions that obscured other cellular details and had a slightly grainy appearance. There was a multifocal moderate inflammatory infiltrate within the epidermis that was mainly lymphohistiocytic, with some neutrophils. Some macrophages contained cell debris within the cytoplasm (Fig. 4a).

Fish had mild, focal to locally extensive necrosis in dermis, subcutis and superficial muscles, with loss of tissue architecture and accumulation of small numbers of inflammatory cells, mainly mononuclear (Fig. 4b). There were moderate numbers of mononuclear cells clustered, probably in blood vessels, adjacent to large nerves. Some of the cells had central clearing of the nuclear chromatin, with refractile, eosinophilic granulation or linear inclusions. The lesions may have been more associated with pale areas (seen as clumping of dermal pigment) than with dark areas, but this was equivocal. Gills did not show significant lesions in any fish, and special stains failed to highlight bacteria or fungi.

A diagnosis was made of severe, diffuse epidermal dysplasia, with multifocal regionally extensive dermal hyperplasia, mild focal lymphocytic dermatitis and superficial myositis. The histological appearance of the lesions was suggestive of a viral infection, and, although the mortality event had resolved itself with restoration of water temperature, scrapings from skin of retained frozen fish were submitted for virus isolation.

Bacteriology. Cultures of skin and gills from 6 fish were negative for all bacterial pathogens, including Flavibacterium columnare, the agent of columnaris disease.

Virus isolation. No CPEs were observed in the FHM cells, but CPE, typical of birnavirus infection, was observed in RTG-2 cells on Day 3 and rapidly progressed to about 80 to $90 \%$ by Day 6 . The second passage of culture supernatant using BF-2 and RTG2 cells at CSIRO resulted in the destruction of cultures within $24 \mathrm{~h}$. 

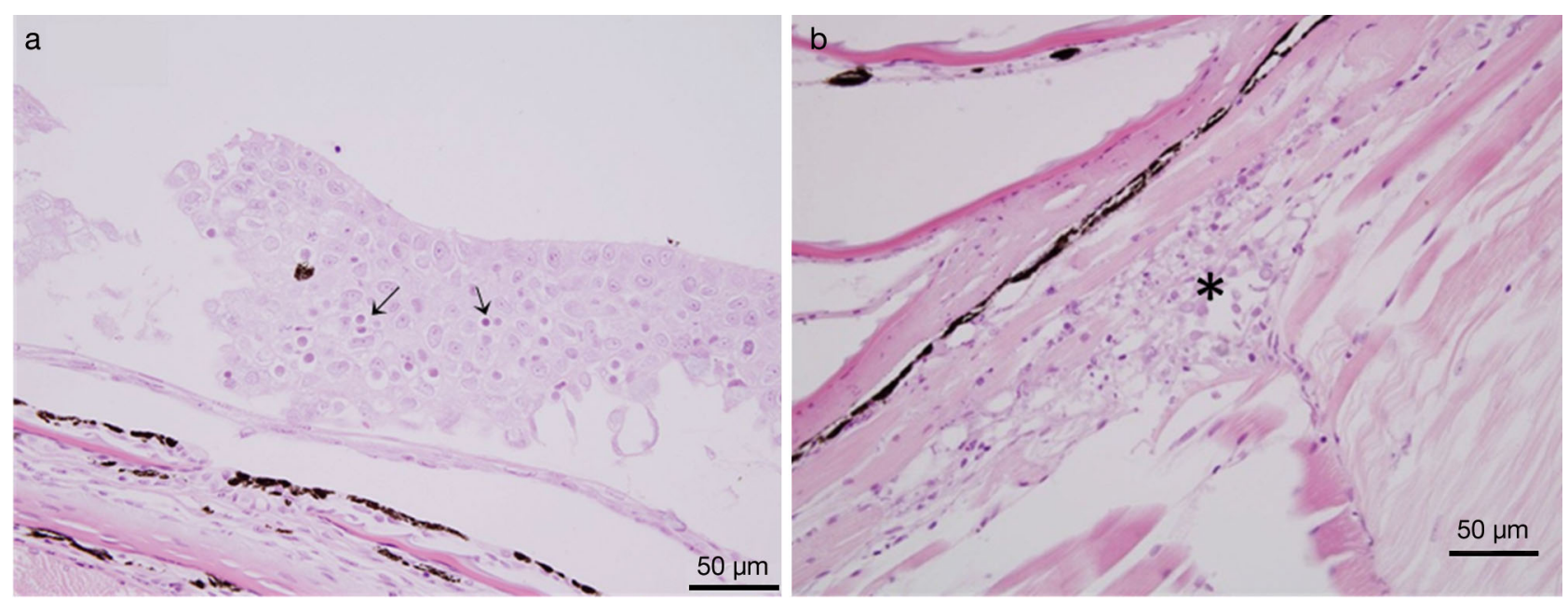

Fig. 4. Oncorhynchus mykiss. (a) Histological photomicrograph of skin and muscle showing small numbers of lymphocytes (arrows) in a thickened and disordered epithelium, with mild muscle necrosis and inflammation seen in some slides. (b) Within superficial muscles focal myositis and myonecrosis, lymphohistiocytic infiltrates and loss of muscle fibres (asterisk) are evident

Electron microscopy. In ultrathin sections virions were observed within the cytoplasm — icosahedral in shape and non-enveloped, with an average diameter of $54 \pm 4 \mathrm{~nm}(\mathrm{n}=12)$. Virions were only observed in cells displaying extensive degranulation of the cytoplasm (Fig. 5). No tubular forms of the virus were identified. Examination of negative-stained prepara-

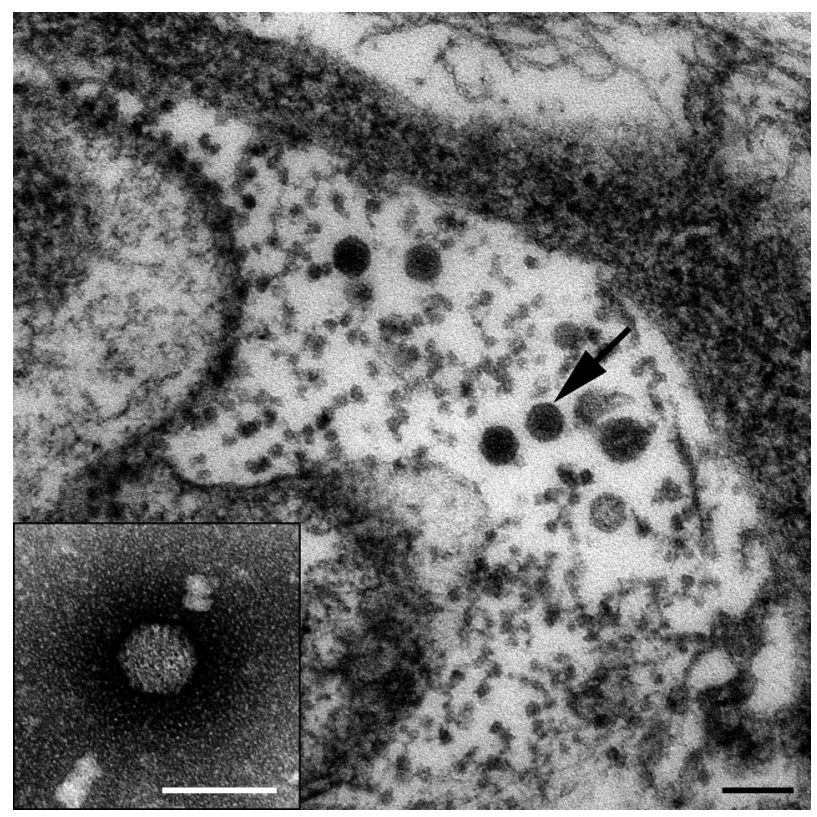

Fig. 5. Transmission electron micrograph of an ultrathin section of an infected CHSE-214 cell. Arrow indicates iscosahedral birnavirus particles within the cytoplasm. Insert: Negative-stained particle with obvious icosahedral symmetry and fine surface detail from an infected RTG-2 cell culture supernatant. Scale bars $=100 \mathrm{~nm}$ tions revealed the presence of naked icosahedral particles $\left(68 \pm 4 \mathrm{~nm}_{i} \mathrm{n}=2\right)$ with hexagonal profiles displaying fine surface detail. These data (shape, size and cytopathology) indicate the viral structures are similar to birnaviruses as described by Delmas et al. (2012).

Molecular analysis. Amplicons of approximately $775 \mathrm{bp}$ size were produced for the 4 replicate extractions tested (Fig. 6). An amplicon of the expected size was also produced for the TABV-positive control. No amplicon was produced for template extracted from uninfected cell culture supernatant, nor from an unrelated aquabirnavirus isolated from swordtails, Xiphophorus helleri (M. S. J. Crane \& N. J. G. Moody unpubl. results). Restriction enzyme digests of purified amplicons using ClaI did not digest the amplicons produced from the test samples but did digest the TABV-positive control, producing 2 fragments of approximately 652 and 123 bp (Fig. 7).

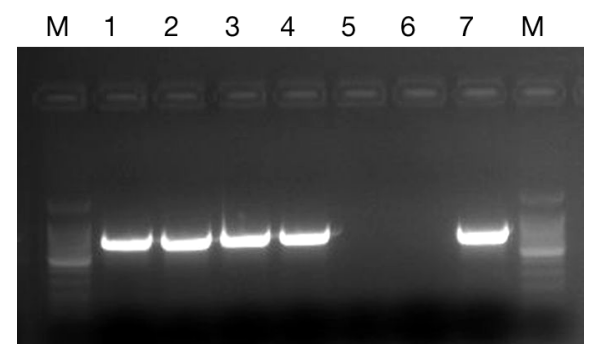

Fig. 6. Amplicons produced by generic aquabirnavirus Serogroup A RT-PCR using the GABF/GABR0 primer set. Test samples (Lanes 1 to 4), no template control (Lane 5), swordtail aquabirnavirus (Lane 6), Tasmanian aquabirnavirus (TABV) (Lane 7), M = 100 bp DNA ladder 


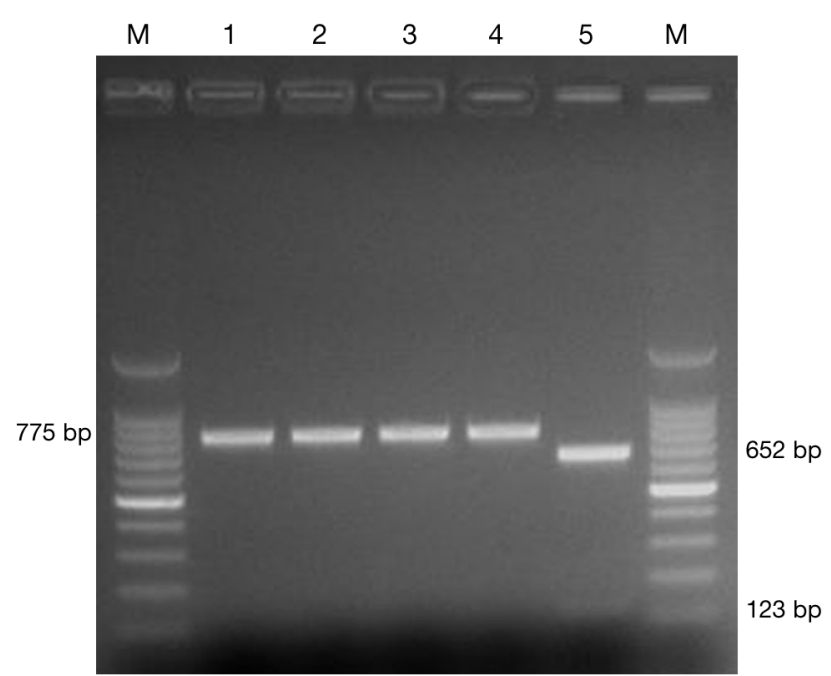

Fig. 7. Amplicons for generic Aquabirnavirus RT-PCR cut from the gel and purified for digestion with ClaI to distinguish Aquabirnavirus (652 and 123 bp bands) from infectious pancreatic necrosis virus (IPNV) (775 bp band). Test samples (Lanes 1 to 4), Tasmanian Aquabirnavirus (Lane 5), $\mathrm{M}=100 \mathrm{bp}$ DNA ladder

Sequencing of purified amplicons generated using the GABF/GABR primer set enabled analysis of a $738 \mathrm{bp}$ consensus sequence from 2 replicates of the rainbow trout isolate and the TABV-positive control. The sequence obtained has the GenBank Accession No. KM504970. The sequences from the 2 amplicons of the rainbow trout isolate were identical to each other, and the TABV-positive control shared a $99.7 \%$ nucleotide similarity with TAB98 (EU672429). The rainbow trout isolate sequence shared only 78.9 and $74.9 \%$ nucleotide similarities with TAB98 (EU672429) and IPNV Erwin (EU869269), respectively. The novel nature of the rainbow trout virus was confirmed by phylogenetic analysis (Fig. 8). The virus has been provisionally named Victorian trout aquabirnavirus (VTAB).

Immunocytochemistry. Cell cultures infected with the rainbow trout aquabirnavirus were test-negative, although positive controls (cultures infected with the Erwin strain of IPNV) showed a positive reaction, as expected (results not shown). These results suggest that the relationship of the virus to IPNV, to which the antibody was raised, was too distant to permit cross reactivity, and no staining of tissue sections was attempted.

\section{DISCUSSION}

The family Birnaviridae consists of 4 genera and a number of unclassified species (Delmas et al. 2012).
One genus, Entomobirnavirus (typified by the Drosophila $\mathrm{X}$ virus) contains species that are principally infective to insects. Infectious bursal disease virus is the sole member of the genus Avibirnavirus, and the type virus for the genus Aquabirnavirus, which contains 3 species and several isolates awaiting classification, is represented by IPNV in salmonids. In 2008 the International Committee on Virus Taxonomy accepted a 4th genus, Blosnavirus, with a single member species, the blotched snakehead virus, which shows a closer relationship to the avian viruses than to the aquatic birnaviruses, despite its origin in a freshwater fish (Da Costa et al. 2003).

Aquabirnaviruses of low pathogenicity have been isolated from farmed Atlantic salmon in sea cages in Macquarie Harbour, Tasmania (Crane et al. 2000, Davies et al. 2010), and a non-pathogenic strain has been isolated from sea-adapted salmon from New Zealand (Tisdall \& Phipps 1987). Viruses have not previously been isolated from freshwater-adapted salmonids in Australia or New Zealand, nor from fish raised in Australian mainland waters.

Following the identification of the aquabirnavirus in Tasmanian waters (Crane et al. 2000), surveillance of salmonid hatcheries in Victoria, including the one described in this report, was undertaken in 2000, but did not turn up evidence of birnaviruses in milt or ovarian fluids inoculated in cultures of CHSE-214 or BF-2 cell lines (Muller et al. 2000). Skin was not examined, and fish were not sacrificed for examination of viscera during this surveillance activity (Muller at al. 2000).

However, although aquabirnavirus isolation from reproductive tract fluids has been validated as a nonlethal screening method (Ahne 1983, McAllister et al. 1987), higher viral titres are achieved when IPNV isolation is attempted from kidney tissues rather than from reproductive secretions (Munro \& Ellis 2008), reflecting the replication of IPNV within leukocytes (Swanson \& Gillespie 1979, Ahne \& Thomsen 1986, Johansson \& Olesen 2009), particularly adherent leukocytes such as those of the renal haematopoietic tissue (Johansson \& Olesen 2009). In eels suffering from aquabirnaviral gill lamellar pillar necrosis, lesions in viscera are often confined to gastric gland cell necrosis, with minimal or no signs in the liver, kidney, or other organs (Lee et al. 1999), suggesting an epithelial tropism for this virus.

In view of this, previous Victorian testing may not have been optimal, particularly for identification of aquabirnaviruses other than IPNV. Moreover, neither native fish nor birds have been screened, so it remains possible that this novel virus may have been 


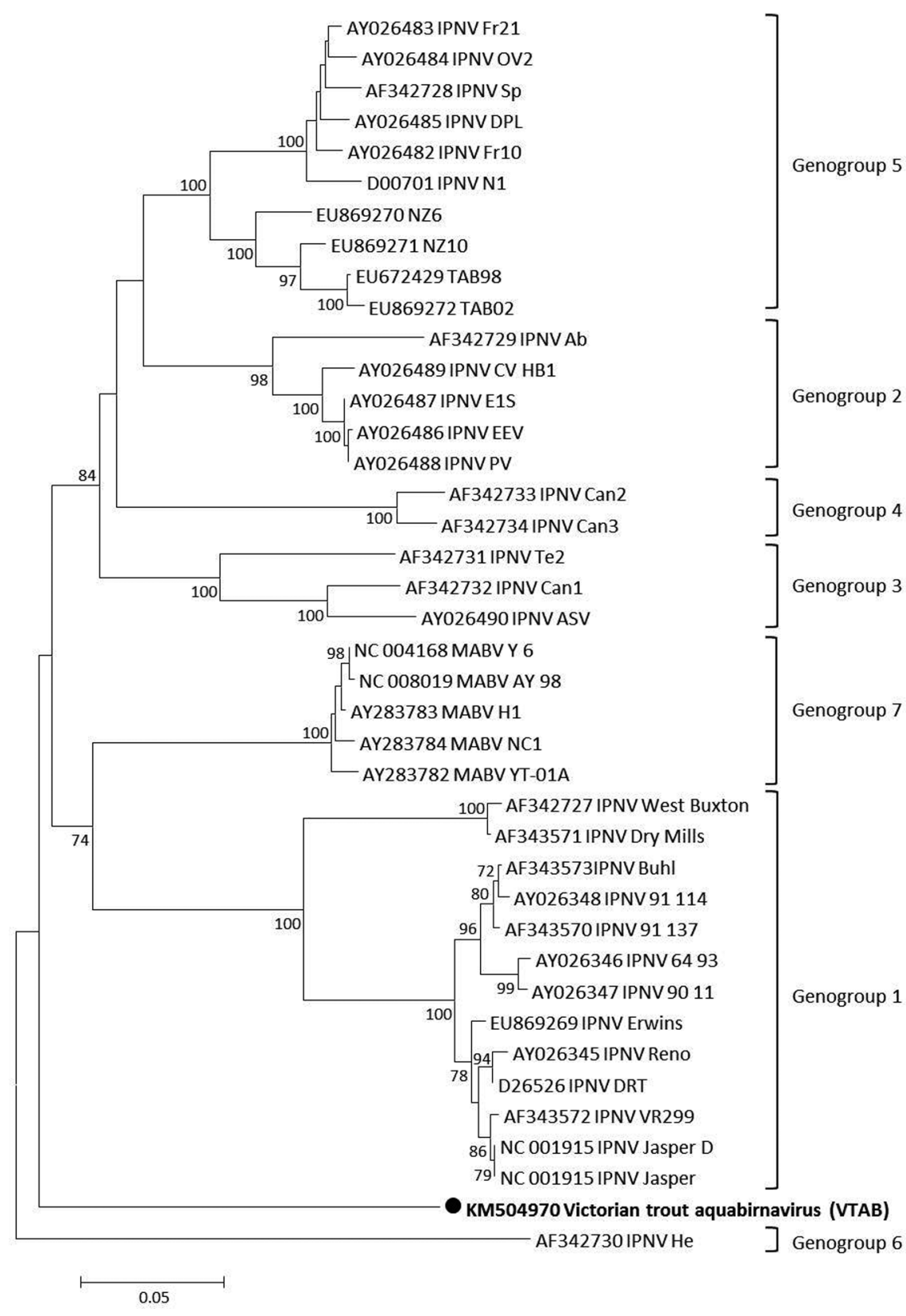

Fig. 8. Phylogenetic analysis of 711 common bases of the Victorian trout aquabirnavirus (VTAB, KM504970) with isolates from the infectious pancreatic necrosis virus (IPNV), Tasmanian aquabirnavirus (TABV) and marine aquabirnavirus (MABV) groups described in Davies et al. (2010), using the neighbour-joining method

and New Zealand fall within Genogroup 5 (Davies et al. 2010). Further molecular characterisation of the Victorian virus and experimental determination of its pathogenicity for trout, other salmonids and native fish have yet to be undertaken.

Skin has not been examined in other cases of aquabirnavirus infection, although mucus and faeces were found to be poorto-negative sources of IPNV in carrier fish (Blake et al. 1995). The status of those tissues in clinically affected fish is not reported and is presumably negative (since negative findings are rarely reported). Kidney was not submitted for virus isolation from the fish reported here because, in the absence of lesions in any viscera and the previously negative survey results, birnavirus infection was not considered a clinical differential diagnosis. The distribution pattern of the new virus in infected fingerlings requires further investigation.

IPNV can be isolated from wild and escaped fish in waters surrounding hatcheries and from surrounding freshwater farms with a past history of IPN (Maheshkumar et al. 1991, McAllister \& Bebak 1997). IPNV has also been isolated from mussels, sediment and sea water during outbreaks of IPN in sea farms (Gregory et al. 2007). Persistence in the marine environment is shortlived - the concentration of virus peaking around a month after a disease event and declining over

present in Victorian waters for an extended period. This possibility is supported by the phylogenetic analysis, which places VTAB by itself, but closer to IPNV and marine birnavirus (Zhang \& Suzuki 2004) isolates than to the Tasmanian or New Zealand birnaviruses. Seven genogroups of Aquabirnavirus are recognised (Blake et al. 2001, Nishizawa et al. 2005), and the above-mentioned isolates from Tasmania the following 6 to 8 mo (Gregory et al. 2007). In the freshwater environment the prevalence in free-ranging fish was reported to be low, and titres in water are approximately 107 -fold lower than those used for the experimental challenge. It is thought unlikely that the low-level exposure possible by this means would be responsible for disease outbreaks (McAllister \& Bebak 1997). 
Deaths from aquabirnavirus infection, both IPNV and others, are greatest in times of high water temperatures (Dorson \& Torchy 1981, Jung et al. 1999, Reno 1999), and in young fish (Dorson \& Torchy 1981, Rodger \& Frerichs 1997, Jung et al. 1999, Roberts \& Pearson 2005). The outbreak on the farm described here is consistent with this finding. Water records for the year in question and the previous $2 \mathrm{yr}$ showed that the temperatures encountered were unusual. It is likely that higher temperatures would be encountered at the height of summer, but the increased age of the fish at that time may decrease their susceptibility to disease.

Other stress factors, including over-stocking/crowding, handling or deterioration of water quality (Rodriguez Saint-Jean et al. 2003) and perhaps other aquatic birnaviruses, may also contribute to outbreaks of IPN, but with the resolution of the white spot infection, no adverse management issues of significance were associated with the outbreak described here, and water oxygenation levels remained within the ranges recorded for preceding months and for the same time of year in preceding years.

In summary, we report here the isolation and identification of a novel aquatic birnavirus from rainbow trout, associated with an episode of increased mortality during a period of high water temperature, and provisionally name it Victorian trout aquabirnavirus (VTAB). This is the first report of an aquabirnavirus from mainland Australian waters, and the first report of isolation from fish in freshwater in Australia or New Zealand. No further mortality episodes have been reported, and the causal relationship between the isolate and fish deaths remains unclear.

Acknowledgements. The authors acknowledge the contributions of Dr Mary Dep and Natalie Kvalheim, DEPI, and Lynette Williams, John Hoad and Kelly Davies, CSIRO AAHL, for expert scientific and technical assistance with bacteriology, histology, virus production, immunocytochemistry and molecular studies.

\section{LITERATURE CITED}

Ahne W (1983) Presence of infectious pancreatic necrosis virus in the seminal fluid of rainbow trout, Salmo gairdneri Richardson. J Fish Dis 6:377

Ahne W, Thomsen I (1986) Infectious pancreatic necrosis: detection of virus and antibodies in rainbow trout IPNVcarrier (Salmo gairdneri). J Vet Med B 33:552-554

Blake SL, Schill WB, McAllister PE, Lee MK, Singer JT, Nicholson BL (1995) Detection and identification of aquatic birnaviruses by PCR assay. J Clin Microbiol 33: 835-839

Blake S, Ma JY, Caporale DA, Jairath S, Nicholson BL (2001) Phylogenetic relationships of aquatic birnaviruses based on deduced amino acid sequences of genome segment $\mathrm{A}$ cDNA. Dis Aquat Org 45:89-102

Crane MSJ, Hardy-Smith P, Williams LM, Hyatt AD and others (2000) First isolation of an aquatic birnavirus from farmed and wild fish species in Australia. Dis Aquat Org 43:1-14

> Da Costa B, Soignier S, Chevalier C, Henry C, Thory C, Huet JC, Delmas B (2003) Blotched snakehead virus is a new aquatic birnavirus that is slightly more related to avibirnavirus than to aquabirnavirus. J Virol 77:719-725

Davies KR, McColl KA, Wang LF, Yu M, Williams LM, Crane MSJ (2010) Molecular characterisation of Australasian isolates of aquatic birnaviruses. Dis Aquat Org 93:1-15

Delmas B, Mundt E, Vakharia VN, Wu JL (2012) Family Birnaviridae. In: King AMQ, Lefkowitz E, Adams MJ, Carstens EB (eds) Virus taxonomy, classification and nomenclature of viruses: 9th report of the International Committee on the Taxonomy of Viruses. Elsevier Academic Press, San Diego, CA, p 499-507

$>$ Dorson M, Torchy C (1981) The influence of fish age and water temperature on mortalities of rainbow trout, Salmo gairdneri Richardson, caused by a European strain of infectious pancreatic necrosis virus. J Fish Dis 4:213-221

Drummond AJ, Ashton B, Buxton S, Cheung M and others (2011) Geneious v5.4. Available at: www.geneious.com

Gregory A, Munro LA, Wallace IS, Bain N, Raynard RS (2007) Detection of infectious pancreatic necrosis virus (IPNV) from the environment in the vicinity of IPNVinfected Atlantic salmon farms in Scotland. J Fish Dis 30: 621-630

Johansson T, Olesen NJ (2009) Detection of infectious pancreatic necrosis virus from rainbow trout, Oncorhynchus mykiss (Walbaum), using the macrophage lysis method. J Fish Dis 32:563-566

Jung SJ, Kitamura S, Kawai K, Suzuki S (1999) Isolation of different types of birnavirus from ayu Plecoglossus altivelis and amago salmon Oncorhynchus rhodurus cultured in the same geographic area. Dis Aquat Org 38: 87-91

> Lee NS, Nomura Y, Miyazaki T (1999) Gill lamellar pillar cell necrosis, a new birnavirus disease in Japanese eels. Dis Aquat Org 37:13-21

> Maheshkumar S, Goyal M, Economon PP (1991) Evaluation of a water concentration method for the detection of infectious pancreatic necrosis virus in a fish hatchery. J Appl Ichthyology 7:115-119

- McAllister PE, Bebak J (1997) Infectious pancreatic necrosis virus in the environment: relationship to effluent from aquaculture facilities. J Fish Dis 20:201-207

> McAllister PE, Owens WJ, Ruppenthal TM (1987) Detection of infectious pancreatic necrosis virus in pelleted cell and particulate components from ovarian fluid of brook trout Salvelinus fontinalis. Dis Aquat Org 2:235-237

Muller JD, Wilks CR, Humphrey JD, Grant P (2000) Surveillance for aquabirnavirus in fish hatcheries in Victoria. Aust Vet J 78:493-494

Munro ES, Ellis AE (2008) A comparison between nondestructive and destructive testing of Atlantic salmon, Salmo salar L., broodfish for IPNV - destructive testing is still the best at time of maturation. J Fish Dis 31: 187-195

Nishizawa T, Kinoshita S, Yoshimizu M (2005) An approach for genogrouping of Japanese isolates of aquabirnaviruses in a new genogroup, VII, based on the VP2/NS junction region. J Gen Virol 86:1973-1978 
Reno PW (1999) Infectious pancreatic necrosis and associated aquatic birnaviruses. In: Woo PTK, Bruno WD (eds) Fish diseases and disorders, Vol 3. Viral, bacterial and fungal infections. CABI Publishing, Wallingford, p 1-55

Roberts RJ, Pearson MD (2005) Infectious pancreatic necrosis in Atlantic salmon, Salmo salar L. J Fish Dis 28: 383-390

Rodger HD, Frerichs GN (1997) Clinical infectious pancreatic necrosis virus infection in farmed halibut in the United Kingdom. Vet Rec 140:401-402

Rodriguez Saint-Jean S, Borrego JJ, Perez-Prieto SI (2003) Infectious pancreatic necrosis virus: biology, pathogenesis, and diagnostic methods. Adv Virus Res 62:113-165

Swanson RN, Gillespie JH (1979) Pathogenesis of infectious pancreatic necrosis in Atlantic salmon, Salmo salar. J Fish Res Board Can 36:587-591

Editorial responsibility: V. Gregory Chinchar, Jackson, Mississippi, USA
Tamura K, Peterson D, Peterson N, Stecher G, Nei M, Kumar S (2011) MEGA5: molecular evolutionary genetics analysis using maximum likelihood, evolutionary distance, and maximum parsimony methods. Mol Biol Evol 28: 2731-2739

Tisdall DJ, Phipps JC (1987) Isolation and characterisation of a marine birnavirus from returning Quinnat salmon (Oncorhynchus tshawtscha) in the South Island of New Zealand. NZ Vet J 35:217-218

> Weir RP, Moody NJG, Hyatt AD, Crameri S, Voysey R, Pallister J, Jerrett IV (2012) Isolation and characterisation of a novel Bohle-like virus from two frog species in the Darwin rural area, Australia. Dis Aquat Org 99:169-177

Zhang CX, Suzuki S (2004) Aquabirnaviruses isolated from marine organisms form a distinct genogroup from other aquavirnaviruses. J Fish Dis 27:633-643

Submitted: November 20, 2014; Accepted: February 5, 2015 Proofs received from author(s): May 13, 2015 